\title{
Halorubrum chaoviator sp. nov., a haloarchaeon isolated from sea salt in Baja California, Mexico, Western Australia and Naxos, Greece
}

\author{
Correspondence \\ Helga Stan-Lotter \\ helga.stan-lotter@sbg.ac.at
}

\author{
Rocco L. Mancinelli, ${ }^{1}$ Ragnhild Landheim, ${ }^{1}$ Cristina Sánchez-Porro, ${ }^{2}$ \\ Marion Dornmayr-Pfaffenhuemer, ${ }^{3}$ Claudia Gruber, ${ }^{3}$ Andrea Legat, ${ }^{3}$ \\ Antonio Ventosa, ${ }^{2}$ Christian Radax, ${ }^{4}$ Kunio Ihara, ${ }^{5}$ Melisa R. White ${ }^{1}$ \\ and Helga Stan-Lotter ${ }^{3}$
}

\author{
${ }^{1}$ SETI Institute, 515 N. Whisman Road, Mountain View, CA 94043, USA \\ ${ }^{2}$ Department of Microbiology and Parasitology, Faculty of Pharmacy, University of Sevilla, 41012 \\ Sevilla, Spain \\ ${ }^{3}$ Division of Molecular Biology, Department of Microbiology, University of Salzburg, Billrothstraße \\ 11, A-5020 Salzburg, Austria \\ ${ }^{4}$ Dr.-Petter-Str. 20, A-5020 Salzburg, Austria \\ ${ }^{5}$ Center for Gene Research, Nagoya University, Nagoya 464-8602, Japan
}

The current classification of halophilic archaea is based on phenotypic characteristics, chemical data (polar lipid composition) and genetic data (16S rRNA gene sequence information and DNA-DNA hybridization) (Oren et al., 1997; Grant et al., 2001). Strains of the genus Halorubrum are known to use carbohydrates as sources of carbon and

The GenBank/EMBL/DDBJ accession numbers for the $16 \mathrm{~S}$ rRNA gene sequences of strains Halo-G*T ${ }^{{ }^{\top}}$, AUS-1 and Naxos II are AM048786, D32081 and AJ400624.

Phase-contrast micrographs of cells of strains Halo- $\mathrm{G}^{* \top}$ and Naxos II and 2D TLC of the polar lipids of strains Halo-G ${ }^{* \top}, A \cup S-1$ and Naxos II are available as supplementary material with the online version of this paper. energy, as was first described for Halorubrum saccharovorum (Tomlinson \& Hochstein, 1976), the type species of the genus (McGenity \& Grant, 2001). At the time of writing, the genus Halorubrum contains 19 species with validly published names: Hrr. saccharovorum (Tomlinson \& Hochstein, 1976), Hrr. sodomense (Oren, 1983), Hrr. lacusprofundi (Franzmann et al., 1988), Hrr. trapanicum (McGenity \& Grant, 1995), Hrr. coriense and Hrr. distributum (Kamekura \& Dyall-Smith, 1995), Hrr. vacuolatum (Kamekura et al., 1997; Grant \& Larsen, 1989), Hrr. tebenquichense (Lizama et al., 2002), Hrr. terrestre (Ventosa et al., 2004), Hrr. tibetense (Fan et al., 2004), Hrr. xinjiangense (Feng et al., 2004), Hrr. alkaliphilum (Feng et al., 2005), Hrr. lipolyticum and Hrr. aidingense (Cui et al., 
2006), Hrr. orientale (Castillo et al., 2006), Hrr. ezzemoulense (Kharroub et al., 2006), Hrr. arcis (Xu et al., 2007), Hrr. litoreum (Cui et al., 2007) and Hrr. ejinorense (Castillo et al., 2007).

We describe here three halophilic archaeal strains that were isolated from a marine intertidal area along the coast of Baja California, Mexico (strain Halo- $\mathrm{G}^{{ }^{\mathrm{T}}} ; 28^{\circ} \mathrm{N} 114^{\circ} \mathrm{W}$ ), natural salt-water pools on the Western Australian coast (strain AUS-1) and from a salt lake on the island of Naxos,

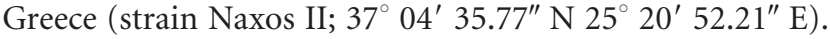
The three strains belong to the genus Halorubrum and proved to be very similar in their properties, suggesting a wide distribution of these haloarchaea. In addition, strain Halo- $G^{* T}$ is of special significance, because it had been dried onto quartz disks and flown on the Biopan facility, a small retrievable capsule developed by the European Space Agency for exposure of biological samples in low Earth orbit (ESA, 2005), and survived exposure to conditions of outer space for 2 weeks (Mancinelli et al., 1998).

All strains were isolated by enrichment in liquid medium and repeated streaking on agar medium as follows. For strain Halo- $\mathrm{G}^{* \mathrm{~T}}$, the medium contained $\left(\mathrm{g} \mathrm{l}^{-1}\right)$ casein hydrolysate (HyCase; Sigma), 5; yeast extract (Difco), 5; $\mathrm{NaCl}, 200 ; \mathrm{KCl}, 2 ; \mathrm{MgCl}_{2} \cdot 6 \mathrm{H}_{2} \mathrm{O}, 20 ; \mathrm{CaCl}_{2} \cdot 2 \mathrm{H}_{2} \mathrm{O}, 0.2$ (adjusted to $\mathrm{pH}$ 7.4). For strain AUS-1, the medium contained ( $\mathrm{g}^{-1}$ ) polypeptone (Daigo Eiyo), 3.3; trisodium citrate, 3; $\mathrm{NaCl}, 250 ; \mathrm{KCl}, 2 ; \mathrm{MgSO}_{4}, 10 ; \mathrm{CaCl}_{2} .2 \mathrm{H}_{2} \mathrm{O}, 0.2$ (adjusted to pH 7.2 with $\mathrm{NaOH}$ ). For strain Naxos II, M2 medium was used, containing $\left(\mathrm{g} \mathrm{l}^{-1}\right)$ HyCase, 5; yeast extract (Difco), 5; Tris, 12.1; $\mathrm{NaCl}, 200 ; \mathrm{KCl}, \quad 2$; $\mathrm{MgCl}_{2} \cdot 6 \mathrm{H}_{2} \mathrm{O}, 20 ; \mathrm{CaCl}_{2} .2 \mathrm{H}_{2} \mathrm{O}, 0.2$ (adjusted to $\mathrm{pH} 7.4$ with $\mathrm{HCl}$ ). For solidification, $20 \mathrm{~g}$ agar $1^{-1}$ was added to each medium. Routine cultivation was in M2 medium at $40{ }^{\circ} \mathrm{C}$ and $\mathrm{pH}$ 7.4. Growth ranges and optima of $\mathrm{NaCl}$ and $\mathrm{MgCl}_{2}$ were determined using the growth medium containing various concentrations of $\mathrm{NaCl}(0.9-5.2 \mathrm{M})$ and $\mathrm{MgCl}_{2}(0-0.5 \mathrm{M})$. Phenotypic tests were performed according to the proposed minimal standards for the description of new taxa in the order Halobacteriales (Oren et al., 1997). The methods used were described previously (Stan-Lotter et al., 2002; Gruber et al., 2004). All tests were performed at least in triplicate with the exception of utilization of amino acids, which was tested in duplicate. Unless otherwise indicated, tests were done in M2 medium at $\mathrm{pH}$ 7.2-7.4 with incubation at $37^{\circ} \mathrm{C}$. The utilization of carbohydrates or amino acids was tested in a semi-defined medium which contained $\left(\mathrm{g} \mathrm{l}^{-1}\right)$ yeast extract, 0.2 ; Tris, 6.05; $\mathrm{NaCl}, 233 ; \mathrm{KCl}, 2 ; \mathrm{MgCl}_{2} \cdot 6 \mathrm{H}_{2} \mathrm{O}, 20 ; \mathrm{CaCl}_{2} .2 \mathrm{H}_{2} \mathrm{O}$, $0.2 ; \mathrm{NH}_{4} \mathrm{Cl}, 0.053$; trace element solution (Malik, 1983), $0.1 \mathrm{ml}$; adjusted to $\mathrm{pH} 7.4$ with $\mathrm{HCl}$. Incubation was done in test tubes without shaking for 7 weeks and utilization of substrates was judged by cellular growth (Stan-Lotter et al., 2002). Susceptibility to antibiotics was tested by spreading cell suspensions on culture plates and applying discs impregnated with the following amounts of antibiotic: ampicillin $(10 \mu \mathrm{g})$, anisomycin $(10 \mu \mathrm{g})$, bacitracin $(10 \mu \mathrm{g})$, chloramphenicol $(10 \mu \mathrm{g})$, erythromycin $(10 \mu \mathrm{g})$, kanamy- cin $(10 \mu \mathrm{g})$, neomycin $(10 \mu \mathrm{g})$, novobiocin $(5 \mu \mathrm{g})$, rifampicin $(10 \mu \mathrm{g})$ and tetracycline $(10 \mu \mathrm{g})$.

Cell motility and morphology were observed under a phase-contrast light microscope and in dark field (Leica DM E). Gram staining of cells was performed according to Dussault (1955). Colony morphology was observed on agar medium under optimal growth conditions after incubation for 30 days.

Polar lipids were extracted with chloroform/methanol as described previously (Stan-Lotter et al., 2002). One- and two-dimensional TLC was performed with silica gel 60 plates $(10 \times 10 \mathrm{~cm})$, using the solvent systems of Kamekura \& Dyall-Smith (1995) and Stan-Lotter et al. (2002), respectively. Detection of phospholipids and functional groups was done as described previously (Stan-Lotter et al., 2002); in addition, sulfated lipids were detected by spraying with $0.016 \%$ azure $\mathrm{A}$ (Sigma) in $1 \mathrm{mM} \mathrm{H}_{2} \mathrm{SO}_{4}$, according to Sprott et al. (2003).

The 16S rRNA genes of strains Halo- $\mathrm{G}^{* \mathrm{~T}}$ and Naxos II were amplified by PCR using the primers Archae21F and 1525R, as described previously (Gruber et al., 2004). The nearly full-length nucleotide sequence (approx. $1400 \mathrm{bp}$ ) was determined for each strain. The $16 \mathrm{~S}$ rRNA gene sequence of strain AUS-1 had been determined and deposited previously (Ihara et al., 1999). The web-based software MEGA 3 (http://www.megasoftware.net; Kumar et al., 2004) was used for sequence analysis and for construction of the phylogenetic tree. Comparison of the sequences with those of members of the family Halobacteriaceae was based on the neighbour-joining method (Saitou \& Nei, 1987). In addition, maximum-parsimony and maximum-likelihood algorithms were used as described previously (Gruber et al., 2004).

Chromosomal DNA for hybridization experiments was isolated and purified according to the methods described by Wilson (1987) and Marmur (1961). Determination of the $\mathrm{G}+\mathrm{C}$ content was performed by the DSMZ Identification Service, following cell disruption with a French press and purification on hydroxyapatite (Cashion et al., 1977). Further details of the method have been described previously (Stan-Lotter et al., 2002). DNA-DNA hybridization studies were performed by the competition procedure of the membrane method (Johnson, 1994), described in detail by Arahal et al. (2001a, b). The hybridization temperature was $57.1{ }^{\circ} \mathrm{C}$, which is within the limit of validity for the filter method (De Ley \& Tijtgat, 1970), and the percentage of hybridization was calculated according to Johnson (1994). The experiments were carried out in triplicate. A few DNA-DNA hybridization experiments were performed by the DSMZ Identification Service (Stan-Lotter et al., 2002), using the thermal renaturation method of De Ley et al. (1970) with modifications by Huß et al. (1983).

The organisms are rods, $2-5 \mu \mathrm{m}$ long. Liquid 96-h cultures of strains Halo- $\mathrm{G}^{* \mathrm{~T}}$, AUS-1 and Naxos II were motile and 
pleomorphic, although rod-shaped cells were most common (see Supplementary Fig. S1, available in IJSEM Online). All three strains were capable of growing over a range of $\mathrm{NaCl}$ concentrations from $2.0 \mathrm{M}(12 \%)$ to $5 \mathrm{M}$ $(30 \%)$. They grew optimally in the presence of $4.3 \mathrm{M}$ $(25 \%) \mathrm{NaCl}$, as has been shown for most extremely halophilic archaea. More details on phenotypic characteristics and results from nutritional tests are given in the species description.

TLC of polar lipids (Supplementary Fig. S2) suggested that all three strains contained phosphatidylglycerol, phosphatidylglyceromethylphosphate and phosphatidylglycerolsulfate derived from $\mathrm{C}_{20} \mathrm{C}_{20}$ glycerol diethers. A sulfated glycolipid S-DGD was also detected. This profile is similar to those reported for the neutrophilic species of Halorubrum (McGenity \& Grant, 2001).

The 16S rRNA gene sequence of strain Halo- $\mathrm{G}^{* \mathrm{~T}}$ was very similar to those of AUS-1 and Naxos II ( $99.8 \%$ similarity to both); it was closely related to those of Hrr. coriense $\mathrm{Ch}^{\mathrm{T}}$ (98.8\%), Hrr. trapanicum NRC $34021^{\mathrm{T}}(98.8 \%)$, Hrr. xinjiangense $\mathrm{BD}-1^{\mathrm{T}}(98.8 \%)$, Hrr. litoreum $\mathrm{Fa}-\mathrm{1}^{\mathrm{T}}$ (98.7\%), Hrr. sodomense ATCC $33755^{\mathrm{T}}$ (98.7\%), Hrr. ejinorense $\mathrm{EJ}-32^{\mathrm{T}}$ (98.2\%), Hrr. distributum JCM $9100^{\mathrm{T}}$ (97.9\%) and Hrr. ezzemoulense $5.1^{\mathrm{T}}$ (97.3\%). Fig. 1 shows a phylogenetic tree that delineates the relationship of the three strains to each other and to the Halorubrum species. Similar topologies were obtained when other treeing methods were used (maximum-parsimony and maximum-likelihood; not shown). The signature sequences A, B and C for the genus Halorubrum (Grant et al., 2001) were present in all three strains without mismatches; Hrr. xingjiangense $\mathrm{BD}-\mathrm{1}^{\mathrm{T}}$ had two mismatches in sequence $\mathrm{C}$ and Hrr. ezzemoulense $5.1^{\mathrm{T}}$ had two inserts in sequence B. In summary, it was concluded that strains Halo- $G^{{ }^{\top}}$, AUS1 and Naxos II formed a new distinct phylogenetic branch within the genus Halorubrum.

The DNA-DNA relatedness between strain Halo- $\mathrm{G}^{* \mathrm{~T}}$ and strains Naxos II and AUS-1 was 75 and $73 \%$, respectively (determined in triplicate). In addition, the 13 Halorubrum type strains that showed $16 \mathrm{~S}$ rRNA gene sequence similarities higher than $97 \%$ with strain Halo- $\mathrm{G}^{* \mathrm{~T}}$ [determined by using the FASTA search and/or the EzTaxon 2.0 program; http://www.eztaxon.org (Chun et al., 2007)] were included in DNA-DNA hybridization experiments. The level of DNA-DNA relatedness between strain Halo- $G^{* T}$ and related Halorubrum species was as follows (three experiments each): $39 \%$ with Hrr. ezzemoulense CECT $7099^{\mathrm{T}}, 35 \%$ with $\mathrm{Hrr}$. ejinorense EJ-32 ${ }^{\mathrm{T}}, 32 \%$ with $\mathrm{Hrr}$. litoreum JCM $13561^{\mathrm{T}}, 31 \%$ with Hrr. coriense $\mathrm{JCM} 9275^{\mathrm{T}}$, $28 \%$ with Hrr. distributum JCM $10118^{\mathrm{T}}, 25 \%$ with Hrr. californensis SF3-213 ${ }^{\mathrm{T}}, 23 \%$ with Hrr. tebenquichense JCM $12290^{\mathrm{T}}, 21 \%$ with $H r r$. xinjiangense JCM $12388^{\mathrm{T}}, 20 \%$ with Hrr. arcis JCM $13916^{\mathrm{T}}$, $19 \%$ with Hrr. terrestre VKM B$739^{\mathrm{T}}, 5 \%$ with Hrr. sodomense JCM $8880^{\mathrm{T}}, 3 \%$ with Hrr. saccharovorum ATCC $29252^{\mathrm{T}}$ and $2 \%$ with Hrr. trapanicum JCM $10477^{\mathrm{T}}$. These data indicated that strain Halo- $\mathrm{G}^{* \mathrm{~T}}$ does not belong to any of these 13 other species, since DNA relatedness values $<70 \%$ have been suggested to justify designation to different species (Wayne et al., 1987); on the other hand, they showed that strains Halo- $\mathrm{G}^{* \mathrm{~T}}$, Naxos II and AUS- 1 are members of the same species.

The phenotypic features, DNA-DNA hybridization values and phylogenetic data based on the 16S rRNA gene sequence comparison clearly supported the placement of strains Halo- $\mathrm{G}^{{ }^{\mathrm{T}}}$, AUS-1 and Naxos II in a novel species of Halorubrum, for which we propose the name Halorubrum chaoviator sp. nov. Table 1 shows features of all three strains that permit differentiation of the novel species from other related Halorubrum species.

\section{Description of Halorubrum chaoviator sp. nov.}

Halorubrum chaoviator [cha.o.vi.a'tor. Gr. n. chaos empty space, the void; L. n. viator traveller; N.L. n. chaoviator (nominative in apposition) the traveller of the void, referring to the exposure of the type strain to conditions of outer space in the Biopan facility].

Cells stain Gram-negative. Cells are pleomorphic, although most are rod-shaped (Supplementary Fig. S1). Cells are approx. 2.0-5.0 $\times 0.5-0.8 \mu \mathrm{m}$. Colonies are circular and red pigmented, $1.5-2 \mathrm{~mm}$ in diameter following incubation for

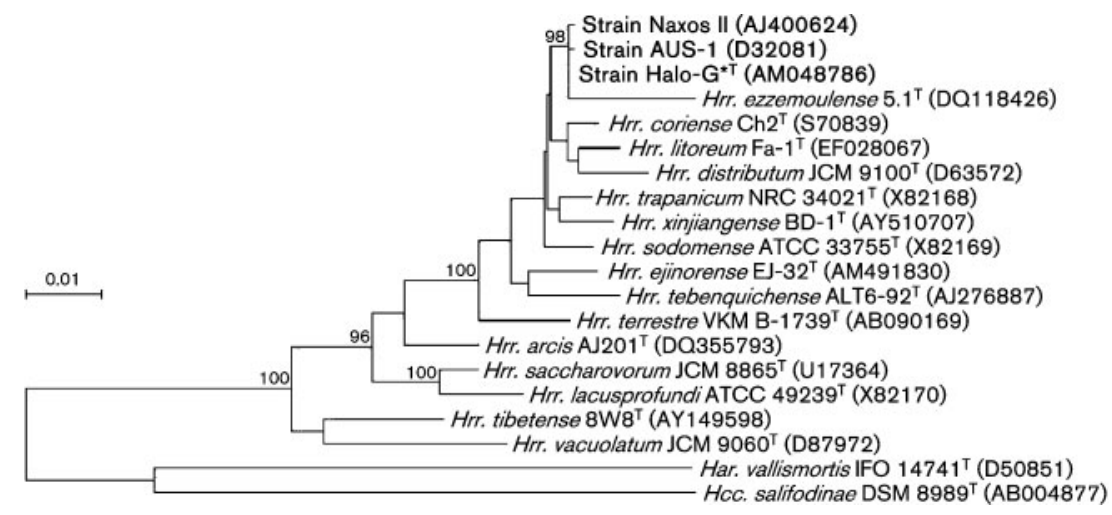

Fig. 1. Phylogenetic tree based on the neighbour-joining algorithm, showing the relationships of strains Halo-G*' ${ }^{* \top}$ AUS-1 and Naxos II and several Halorubrum type strains. The tree is based on an alignment of 16S rRNA gene sequences. Sequence accession numbers are given in parentheses. Bootstrap values higher than 80 out of 100 subreplicates are indicated at the respective bifurcations. The sequences of Haloarcula vallismortis IFO $14741^{\top}$ and Halococcus salifodinae DSM $8989^{\top}$ were used as the outgroup. Bar, 0.01 expected changes per site. 
Table 1. Differential characteristics of strains Halo-G*' ${ }^{* \top}$ AUS-1 and Naxos II and type strains of related Halorubrum species

Strains used for comparison: 1, Hrr. coriense DSM 10284 ${ }^{\mathrm{T}}$; 2, Hrr. trapanicum JCM 10477 ${ }^{\mathrm{T}}$; 3, Hrr. xinjiangense JCM 12388 ${ }^{\mathrm{T}}$; 4, Hrr. litoreum JCM $13561^{\mathrm{T}}$; 5, Hrr. sodomense ATCC $33755^{\mathrm{T}}$; 6, Hrr. ejinorense CECT $7194^{\mathrm{T}}$; 7, Hrr. ezzemoulense CECT $7099^{\mathrm{T}}$. Unless indicated, data for reference strains were taken from McGenity \& Grant (2001), Feng et al. (2004), Kharroub et al. (2006), Castillo et al. (2007) and Cui et al. (2007). +, Positive; -, negative; PGS, phosphatidylglycerolsulfate; ND, no data available.

\begin{tabular}{|c|c|c|c|c|c|c|c|c|c|c|}
\hline Feature & Halo-G ${ }^{\star T}$ & AUS-1 & Naxos II & 1 & 2 & 3 & 4 & 5 & 6 & 7 \\
\hline Cell width $(\mu \mathrm{m})$ & 0.8 & 0.8 & $0.5-0.8$ & 0.5 & $0.7-1.0$ & $0.8-1.2$ & $0.3-0.5$ & 0.5 & $1.0-1.5$ & 0.6 \\
\hline Pigmentation $\neq$ & $\mathrm{RD}$ & $\mathrm{RD}$ & $\mathrm{RD}$ & $\mathrm{RD}-\mathrm{O}$ & PO & $\mathrm{RD}$ & $\mathrm{RD}$ & $\mathrm{O}-\mathrm{RD}$ & $\mathrm{RD}$ & $\mathrm{RD}$ \\
\hline Motility & + & + & + & + & - & + & + & + & - & + \\
\hline Growth at $10{ }^{\circ} \mathrm{C}$ & - & - & - & - & - & + & ND & - & ND & ND \\
\hline $\mathrm{Mg}^{2+}$ requirement & $50 \mathrm{mM}$ & None & $20 \mathrm{mM}$ & $5 \mathrm{mM}$ & $\mathrm{ND}$ & None & $30 \mathrm{mM}$ & $5 \mathrm{mM}$ & None & Required \\
\hline Nitrite from nitrate & - & + & - & - & ND & - & + & $\mathrm{ND}$ & + & + \\
\hline \multicolumn{11}{|l|}{ Hydrolysis of: } \\
\hline Starch & + & - & + & +11 & - & - & - & + & - & - \\
\hline$(-)$-D-Fructose & + & + & + & + & + & + & - & + & - & - \\
\hline$(+)$-D-Galactose & + & + & + & +11 & + & - & + & + & - & - \\
\hline Sucrose & - & - & - & + & + & + & + & - & - & + \\
\hline Lactose & + & + & + & +11 & - & - & - & + & - & - \\
\hline Maltose & + & + & + & +11 & + & + & + & + & - & + \\
\hline \multicolumn{11}{|l|}{ Presence of: } \\
\hline PGS & + & + & + & + & + & + & + & + & - & + \\
\hline S-DGD & + & + & + & + & + & + & + & + & - & + \\
\hline $\mathrm{G}+\mathrm{C}$ content $(\mathrm{mol} \%)$ & 65.5 & 65.5 & 66.5 & 67.311 & 64.3 & 68.0 & 64.9 & 67.4 & 61.0 & 61.9 \\
\hline
\end{tabular}

$\dagger \mathrm{LR}$, Long rod; P, pleomorphic; R, rod; SR, short rod.

$\neq \mathrm{O}$, Orange; PO, pale orange; $\mathrm{RD}$, red.

$\S$ Very slow growth, after about 4 weeks.

IIData from this study.

30 days at $37{ }^{\circ} \mathrm{C}$. Growth occurs at pH 7.0-8.5, $28-50{ }^{\circ} \mathrm{C}$ and $\mathrm{NaCl}$ concentrations of $2.0-5.0 \mathrm{M}(12-30 \%)$. No growth at $10{ }^{\circ} \mathrm{C}$. Optimal growth occurs at $\mathrm{pH} 7.4,37{ }^{\circ} \mathrm{C}$ and $4.3 \mathrm{M}(25 \%) \mathrm{NaCl}$. Extremely halophilic; cells lyse in water. The requirement for magnesium is variable among strains. Chemo-organotrophic, aerobic and oxidase- and catalase-positive. $\beta$-Galactosidase-positive; $\alpha$-galactosidase activity is variable among strains. Anaerobic growth with nitrate or L-arginine does not occur. Tween 80 , aesculin and gelatin are not hydrolysed. Starch hydrolysis and nitrate reduction to nitrite are variable among strains. Indole is not formed. Acid is produced from $(+)$-Dglucose, (+)-D-galactose, lactose and maltose, but not from (-)-D-fructose or sucrose. The following substrates are utilized as sole carbon and energy sources: $(+)$-Dgalactose, $(+)$-D-glucose, $(-)$-D-fructose, maltose and lactose. No growth occurs on sucrose, L-arginine, L- glutamic acid or DL-phenylalanine. Polar lipids include phosphatidylglycerol, phosphatidylglyceromethylphosphate and phosphatidylglycerolsulfate derived from $\mathrm{C}_{20} \mathrm{C}_{20}$ glycerol diethers and the sulfated glycolipid S-DGD. Susceptible to bacitracin and novobiocin; not susceptible to ampicillin, anisomycin, chloramphenicol, erythromycin, kanamycin, neomycin, rifampicin or tetracycline. The DNA G + C content of the three known strains is 65.5$66.5 \mathrm{~mol} \%\left(T_{\mathrm{m}}\right)$.

The type strain is strain Halo- ${ }^{* T}$ (=DSM $19316^{\mathrm{T}}$ $=$ NCIMB $14426^{\mathrm{T}}=$ ATCC BAA-1602 ${ }^{\mathrm{T}}$ ), which was isolated from an evaporitic salt crystal from Baja California, Mexico. Its $\mathrm{G}+\mathrm{C}$ content is $65.5 \mathrm{~mol} \%$. Strains AUS-1 (=JCM 9573) and Naxos II, reference strains of the species, were isolated from Western Australia and the Greek island of Naxos, respectively. 


\section{Acknowledgements}

This work was supported in part by the Austrian Science Funds (FWF), project P16260 (to H.S.-L.), and the NASA Astrobiology Institute Cooperative Agreement NNA04CC05A (to R. L. M.). We thank Michael Sulzner, Austrian Ministry of Health, for help with the isolation of strain Naxos II.

\section{References}

Arahal, D. R., García, M. T., Ludwig, W., Schleifer, K. H. \& Ventosa, A. (2001a). Transfer of Halomonas canadensis and Halomonas israelensis to the genus Chromohalobacter, as Chromohalobacter canadensis comb. nov. and Chromohalobacter israelensis comb. nov. Int J Syst Evol Microbiol 51, 1443-1448.

Arahal, D. R., García, M. T., Vargas, C., Cánovas, D., Nieto, J. J. \& Ventosa, A. (2001b). Chromohalobacter salexigens sp. nov., a moderately halophilic species that includes Halomonas elongata DSM 3043 and ATCC 33174. Int J Syst Evol Microbiol 51, 1457-1462.

Cashion, P., Holder-Franklin, M. A., McCully, J. \& Franklin, M. (1977). A rapid method for the base ratio determination of bacterial DNA. Anal Biochem 81, 461-466.

Castillo, A. M., Gutiérrez, M. C., Kamekura, M., Xue, Y., Ma, Y., Cowan, D. A., Jones, B. E., Grant, W. D. \& Ventosa, A. (2006). Halorubrum orientale sp. nov., a halophilic archaeon isolated from Lake Ejinor, Inner Mongolia, China. Int J Syst Evol Microbiol 56, 2559-2563.

Castillo, A. M., Gutiérrez, M. C., Kamekura, M., Xue, Y., Ma, Y., Cowan, D. A., Jones, B. E., Grant, W. D. \& Ventosa, A. (2007). Halorubrum ejinorense sp. nov., isolated from Lake Ejinor, Inner Mongolia, China. Int J Syst Evol Microbiol 57, 2538-2542.

Chun, J., Lee, J.-H., Jung, Y., Kim, M., Kim, S., Kim, B. K. \& Lim, Y. W. (2007). EzTaxon: a web-based tool for the identification of prokaryotes based on $16 \mathrm{~S}$ ribosomal RNA gene sequences. Int J Syst Evol Microbiol 57, 2259-2261.

Cui, H. L., Tohty, D., Zhou, P. J. \& Liu, S. J. (2006). Halorubrum lipolyticum sp. nov. and Halorubrum aidingense sp. nov., isolated from two salt lakes in Xin-Jiang, China. Int J Syst Evol Microbiol 56, 1631-1634.

Cui, H.-L., Lin, Z.-Y., Dong, Y., Zhou, P.-J. \& Liu, S.-J. (2007). Halorubrum litoreum sp. nov., an extremely halophilic archaeon from a solar saltern. Int J Syst Evol Microbiol 57, 2204-2206.

De Ley, J. \& Tijtgat, R. (1970). Evaluation of membrane filter methods for DNA-DNA hybridization. Antonie van Leeuwenhoek 36, 461-474.

De Ley, J., Cattoir, H. \& Reynaerts, A. (1970). The quantitative measurement of DNA hybridization from renaturation rates. Eur $J$ Biochem 12, 133-142.

Dussault, H. P. (1955). An improved technique for staining red halophilic bacteria. J Bacteriol 70, 484-485.

ESA (2005). FOTON retrievable capsules. In European Users Guide to Low Gravity Platforms, chapter 6. Noordwijk, Netherlands: European Space Agency. http://www.spaceflight.esa.int/users/downloads/userguides/chapter_6_foton.pdf

Fan, H., Xue, Y., Ma, Y., Ventosa, A. \& Grant, W. D. (2004). Halorubrum tibetense sp. nov., a novel haloalkaliphilic archaeon from Lake Zabuye in Tibet, China. Int J Syst Evol Microbiol 54, 1213-1216.

Feng, J., Zhou, P. J. \& Liu, S. J. (2004). Halorubrum xinjiangense sp. nov., a novel halophile isolated from saline lakes in China. Int J Syst Evol Microbiol 54, 1789-1791.

Feng, J., Zhou, P., Zhou, Y. G., Liu, S. J. \& Warren-Rhodes, K. (2005). Halorubrum alkaliphilum sp. nov., a novel haloalkaliphile isolated from a soda lake in Xinjiang, China. Int J Syst Evol Microbiol 55, $149-152$.
Franzmann, P. D., Stackebrandt, E., Sanderson, K., Volkman, J. K., Cameron, D. E., Stevenson, P. L., McMeekin, T. A. \& Burton, H. R. (1988). Halobacterium lacusprofundi sp. nov., a halophilic bacterium isolated from Deep Lake, Antarctica. Syst Appl Microbiol 11, 20-27.

Grant, W. D. \& Larsen, H. (1989). Group III. Extremely halophilic archaebacteria. Order Halobacteriales ord. nov. In Bergey's Manual of Systematic Bacteriology, vol. 3, pp. 2216-2219. Edited by J. T. Staley, M. P. Bryant, N. Pfennig \& J. G. Holt. Baltimore: Williams \& Wilkins.

Grant, W. D., Kamekura, M., McGenity, T. J. \& Ventosa, A. (2001). Order I. Halobacteriales Grant and Larsen 1989b, 495 VP (Effective publication: Grant and Larsen 1989a, 2216). In Bergey's Manual of Systematic Bacteriology, 2nd edn, vol. 1, pp. 294-299. Edited by D. R. Boone, R. W. Castenholz \& G. M. Garrity. New York: Springer.

Gruber, C., Legat, A., Pfaffenhuemer, M., Radax, C., Weidler, G., Busse, H. J. \& Stan-Lotter, H. (2004). Halobacterium noricense sp. nov., an archaeal isolate from a bore core of an alpine Permian salt deposit, classification of Halobacterium sp. NRC-1 as a strain of $H$. salinarum and emended description of H. salinarum. Extremophiles $\mathbf{8}$, 431-439.

Huß, V. A. R., Festl, H. \& Schleifer, K. H. (1983). Studies on the spectrophotometric determination of DNA hybridization from renaturation rates. Syst Appl Microbiol 4, 184-192.

Ihara, K., Umemura, T., Katagiri, I., Kitajima-Ihara, T., Sugiyama, Y., Kimura, Y. \& Mukohata, Y. (1999). Evolution of the archaeal rhodopsins: evolution rate changes by gene duplication and functional differentiation. J Mol Biol 285, 163-174.

Johnson, J. L. (1994). Similarity analysis of DNAs. In Methods for General and Molecular Bacteriology, pp. 655-681. Edited by P. Gerhardt, R. G. E. Murray, W. A. Wood \& N. R. Krieg. Washington, DC: American Society for Microbiology.

Kamekura, M. \& Dyall-Smith, M. L. (1995). Taxonomy of the family Halobacteriaceae and the description of two genera Halorubrobacterium and Natrialba. J Gen Appl Microbiol 41, 333-350.

Kamekura, M., Dyall-Smith, M. L., Upasani, V., Ventosa, A. \& Kates, M. (1997). Diversity of alkaliphilic halobacteria: proposals for transfer of Natronobacterium vacuolatum, Natronobacterium magadii, and Natronobacterium pharaonis to Halorubrum, Natrialba, and Natronomonas gen. nov., respectively, as Halorubrum vacuolatum comb. nov., Natrialba magadii comb. nov., and Natronomonas pharaonis comb. nov., respectively. Int J Syst Bacteriol 47, 853-857.

Kharroub, K., Quesada, T., Ferrer, R., Fuentes, S., Aguilera, M., Boulahrouf, A., Ramos-Cormenzana, A. \& Monteoliva-Sanchez, M. (2006). Halorubrum ezzemoulense sp. nov., a halophilic archaeon isolated from Ezzemoul sabkha, Algeria. Int J Syst Evol Microbiol 56, 1583-1588.

Kumar, S., Tamura, K. \& Nei, M. (2004). MEGA3: integrated software for molecular evolutionary genetics analysis and sequence alignment. Brief Bioinform 5, 150-163.

Lizama, C., Monteoliva-Sánchez, M., Suárez-García, A., RossellóMora, R., Aguilera, M., Campos, V. \& Ramos-Cormenzana, A. (2002). Halorubrum tebenquichense sp. nov, a novel halophilic archaeon isolated from the Atacama Saltern, Chile. Int J Syst Evol Microbiol 52, 149-155.

Malik, K. A. (1983). A modified method for the cultivation of phototrophic bacteria under anaerobic conditions. J Microbiol Methods 1, 343-352.

Mancinelli, R. L., White, M. R. \& Rothschild, L. J. (1998). Biopansurvival I: exposure of the osmophiles Synechococcus sp. (Nägeli) and Haloarcula sp. to the space environment. Adv Space Res 22, 327-334.

Marmur, J. (1961). A procedure for the isolation of deoxyribonucleic acid from microorganisms. J Mol Biol 3, 208-218. 
McGenity, T. J. \& Grant, W. D. (1995). Transfer of Halobacterium saccharovorum, Halobacterium sodomense, Halobacterium trapanicum NRC 34021 and Halobacterium lacusprofundi to the genus Halorubrum gen. nov., as Halorubrum saccharovorum comb. nov., Halorubrum sodomense comb. nov., Halorubrum trapanicum comb. nov., and Halorubrum lacusprofundi comb. nov. Syst Appl Microbiol 18, 237-243.

McGenity, T. J. \& Grant, W. D. (2001). Genus VII. Halorubrum McGenity and Grant 1996, 362 ${ }^{\mathrm{VP}}$ (Effective publication: McGenity and Grant 1995, 241). In Bergey's Manual of Systematic Bacteriology, 2nd edn, vol. 1, pp. 320-324. Edited by D. R. Boone, R. W. Castenholz \& G. M. Garrity. New York: Springer.

Oren, A. (1983). Halobacterium sodomense sp. nov., a Dead Sea halobacterium with an extremely high magnesium requirement. Int $J$ Syst Bacteriol 33, 381-386.

Oren, A., Ventosa, A. \& Grant, W. D. (1997). Proposed minimal standards for description of new taxa in the order Halobacteriales. Int J Syst Bacteriol 47, 233-238.

Saitou, N. \& Nei, M. (1987). The neighbor-joining method: a new method for reconstructing phylogenetic trees. Mol Biol Evol 4, 406-425.

Sprott, G. D., Sad, S., Fleming, L. P., Dicaire, C. J., Patel, G. B. \& Krishnan, L. (2003). Archaeosomes varying in lipid composition differ in receptor-mediated endocytosis and differentially adjuvant immune responses to entrapped antigen. Archaea 1, 151-164.
Stan-Lotter, H., Pfaffenhuemer, M., Legat, A., Busse, H. J., Radax, C. \& Gruber, C. (2002). Halococcus dombrowskii sp. nov., an archaeal isolate from a Permo-Triassic alpine salt deposit. Int J Syst Evol Microbiol 52, 1807-1814.

Tomlinson, G. A. \& Hochstein, L. I. (1976). Halobacterium saccharovorum sp. nov., a carbohydrate-metabolizing, extremely halophilic bacterium. Can J Microbiol 22, 587-591.

Ventosa, A., Gutierrez, M. C., Kamekura, M., Zvyagintseva, I. S. \& Oren, A. (2004). Taxonomic study of Halorubrum distributum and proposal of Halorubrum terrestre sp. nov. Int J Syst Evol Microbiol 54, 389-392.

Wayne, L. G., Brenner, D. J., Colwell, R. R., Grimont, P. A. D., Kandler, O., Krichevsky, M. I., Moore, L. H., Moore, W. E. C., Murray, R. G. E. \& other authors (1987). International Committee on Systematic Bacteriology. Report of the ad hoc committee on reconciliation of approaches to bacterial systematics. Int J Syst Bacteriol 37, 463-464.

Wilson, K. (1987). Preparation of genomic DNA from bacteria. In Current Protocols in Molecular Biology, pp. 2.4.1-2.4.5. Edited by F. M. Ausubel, R. Brent, R. E. Kingston, D. D. Moore, J. G. Seidman, J. A. Smith \& K. Struhl. New York: Green Publishing \& Wiley-Interscience.

Xu, X.-W., Wu, Y.-H., Zhang, H. B. \& Wu, M. (2007). Halorubrum arcis sp. nov., an extremely halophilic archaeon isolated from a saline lake on the Qinghai-Tibet Plateau, China. Int J Syst Evol Microbiol 57, 1069-1072. 